Izvorni znanstveni rad - UDK - 159.9:004.738.5

316.77

\title{
Analysis of Superposters' Motives for Participating in Online Forum Discussions
}

\author{
Irena Miljković Krečar, Maja Kolega \\ Veleučilište VERN', Zagreb, Hrvatska
}

\begin{abstract}
The main aim of this study was to identify factors which motivate daily participation of extremely active online forum members. An extensive online questionnaire was constructed and sent to the Forum.hr members with more than 8,000 posts. The final sample consisted of 112 respondents. Principal components analysis provided an interpretable three components solution, explaining $54.6 \%$ of the item variance. The components were labelled as self-esteem, information exchange, and confrontation. Some significant differences were also found among motivational subscales and variables of gender, age, and the intensity of forum activity. Results are discussed in relation to previous research.
\end{abstract}

Keywords: online social behaviours, motives of forum communication, superposters, questionnaire

\section{Introduction}

Computer-mediated communication (CMC) refers to any human communication achieved through or with the help of computer technology (Thurlow, Lengel, \& Tomic, 2004, p. 15). Understanding the basic motivation for active participation in CMC is crucial for a deeper understanding of the way the media meets the needs of their users. Uses and gratification theory $(U G T)$ is frequently applied as a theoretical background for numerous research of studies on the motives for media use. This theoretical approach investigates why and how individuals use mass media (Ruggeiro, 2000). Lee, Kim, and Rosen (2009) found that, although the majority of research is not based on a specific theory, Uses and gratifications theory accounted for $17.24 \%$ of the theories applied in the internet and online media research. The general theoretical conclusion of many studies in this field is that the use of a particular medium is motivated by the type of sought gratification. According to Stafford, Stafford, and Schkade (2004), there are three main categories of the internet-used gratifications: content gratification (need for finding specific

Irena Miljković Krečar, Veleučilište VERN', Trg bana Josipa Jelačića 3, 10000 Zagreb, Hrvatska. E-pošta: irena.miljkovic@vern.hr 
information), process gratification (gratification from the experience of purposeful navigating or randomly browsing the internet), and social gratification (forming and deepening social ties). Although results of many studies fall under this rough categorization, it seems that they heavily depend on the type of media under investigation, sample of participants and applied measures.

For example, Papacharissi and Rubin (2000) constructed a 27 items internet motives scale (in general) and administered it to a sample of 279 college students. The factor analysis revealed five factors interpreted as: interpersonal utility (the most salient one), pass time, information seeking, convenience, and entertainment. While the most motives correlated moderately, further investigation showed that the information seeking was the strongest motive for participants who were more financially secure, satisfied with life and comfortable with approaching others in an interpersonal context. On the other hand, those participants who avoided face-to-face interaction, or found it to be less rewarding, who were less satisfied with their lives and who felt less valued in their face-to-face communication used the internet as a functional alternative to interpersonal communication. Furthermore, using the internet for interpersonal utility and for information seeking was negatively related.

Korgaonkar and Wolin (1999) also constructed a 41-item scale measuring motivation for the use of web. The scale was applied to 401 consumers. The factor analysis yielded 7 factors: social escapism (web as a mean for escaping the reality), gaining information, interactive control motivation (the freedom to choose among various contents), socialization, and economic motivation (the remaining two are related to the web usage security and are not relevant in this context). The dependent variables in this research were the purpose (overall usage, personal and business usage, and shopping usage) and the amount of time spent online. All of the listed five factors proved to be significantly and positively related to the amount of time spent online. Moreover, heavier users of the web for private purposes were participants of younger age, less educated and with lower incomes.

Price, Leong, and Ryan (2005) conducted a research on motives of social internet use, on a sample of 270 university students. They applied a 26-item scale. The factor analysis provided three interpretable factors labelled as: information exchange factor (as the most salient one), time and entertainment factor (performing social internet activities by passing time), and altruism factor (the least salient one). The authors tested gender differences and found that males were more likely to use social internet for the purpose of passing time and entertainment, while for females the altruism factor was significantly more present.

Leung (2013) also investigated the underlying structure of motivation for generating content using social media (Facebook, blogs and forums). The total of 596 participants was tested with 23 -item scale. The exploratory factor analysis yielded five factors: social and affection needs (showing others encouragement, sharing interest, views, and thoughts), venting negative feelings (to voice discontent, get anger off one's chest, and fight back against something unfair), recognition needs 
(to promote or publicize their expertise, establish their personal identity, and gain respect and support), entertainment needs (for fun, entertaining, relaxing, and pastime activity) and cognitive needs (to broaden one's knowledge base and to refine one's thinking). The usage of all three social media proved to be significantly correlated with social/affective needs, entertainment, and recognition needs. On the other hand, venting negative feelings and cognitive needs were more related to the use of forums. The latter was explained by the fact that in forums users communicate anonymously and in a more asynchronous fashion. Also, the variety of topics allows them to learn from reading others' posts. As for the entertainment usage of forums, results show that it is more present with the young and the less educated participants.

As opposed to other social media, forums are specific as they allow online discussions about an enormous variety of topics with people from all around the world. They can serve as an effective learning tool (Hernández-Ramos, 2004; Keeler \& Horney, 2007; Palmer, Holt, \& Bray, 2008; Thomas, 2002), influential source of consumer information (Cheung, Lee, \& Rabjohn, 2008; Pitta \& Fowler, 2005) and facilitate expression of political attitudes (Malaspina, 2013; Wojcieszak \& Mutz, 2009).

The latter can be mostly attributed to the forum's anonymity, i.e. no one knows the true identity of participants - who they are, what they look like and where they are from. Anonymity also makes people more open in sharing negative thoughts online. Lapidot-Lefler and Barak (2012) found that the lack of eye-contact was the major contributor to the negative effects of online disinhibition. When forum participants get offended they can offend back, if they get criticized they can find other like-minded, or shut down their account and create another one. On the other hand, forum moderators take care that highly offensive posts are deleted (as well as the repeatedly offensive users), so permanent negative social consequences (as cyberbullying or unfriending on social networks) are less present and less intense in forum communication.

Woong Yun and Park (2011) point out that forum anonymity can eliminate the fear of isolation, a psychological state in which people are afraid of being psychologically or socially sanctioned for expressing an unpopular opinion. These authors found a difference in the level of the fear of isolation between posters and lurkers, concluding that people with low fear of isolation were more likely to post. Consequently, that increases the number of majority opinion postings on the forum and minority opinion becomes less and less visible. However, opportunities of broader reach to similar-minded individuals make forums beneficial for different stigmatized groups of people including HIV/AIDS patients (Graffigna \& Bosio, 2008), anorexia patients (McCormack \& Coulson, 2009), people with autism (Brownlow, 2007), stigmatised illness of a psychiatric nature (Berger, Wagner, \& Baker, 2005; Horgan \& Sweeney, 2010), disabilities (Seymore \& Lupton, 2004), suicide intentions (Barack, 2007), cancer patients (Seale, Ziebland, \& CharterisBlack, 2006), etc. Through online forums, those individuals that usually make 
minority in their own live surroundings, can share experiences and get emotional support in a safe environment. Kummervold et al. (2002) emphasize that majority of mental health forum participants preferred talking about personal problems online and around half of them did not discuss these problems offline.

Finfgeld (2000) identified the main advantages and disadvantages of online support groups. The global accessibility of sites, 24-hour access, anonymity and reduction of social cues (age, race etc.) are, surely, great advantages. The most commonly reported disadvantages were the lack of nonverbal communication and the level of information accuracy.

Another insight into forum-user point of view is given in the research by Rojo and Ragsdale (1997). They conducted a quantitative study of 187 forum participants and additional qualitative study of 12 participants, in order to determine patterns of forum use. Participants showed three modes of forum use. The first one, called fishing for information mode was the most preferred but the least involved mode. Forums are seen as sources of information and updates in a field or interests, but participants rarely contribute and if they do they provide factual or experience related information. The second is called enjoying debate mode, and although the majority of interviewees only lurk forum discussions, a few approach the forums as an interactive medium that allows them to express their views, read other people's views, and argue ideas with others. The third mode is called social networking mode, which, as the name suggests, assumes approaching the forums as an interactive medium that allows meeting other people and building and keeping social contacts. Although the three modes can coexist, only a few participants found the latter mode present.

Graham and Wright (2013) state that in online forum settings, in general, there is a highly active minority, and that their engagement could follow the 1/9/90 rule, which predicts that only $1 \%$ of users of a forum actually post, with $90 \%$ lurking (viewing without posting) and 9\% editing. Although lurking is also beneficial for those who may not feel ready to participate, it is interesting who the posters are and what their motivation to create content and share knowledge through online forums is. Graham and Wright also point out that although there are many typologies of forum participation (e.g. trolls, experts, information seekers, opinion leaders and repliers), almost none of them address the volume of participation. So they propose a categorization of the so-called superparticipants, the ones who participate above the average, either by starting at least 200 new topics (so-called agenda-setters) or by posting within existing ones with more than 2,000 posts, on a forum with over a 100,000 messages (so-called superposters). The third group of superparticipants consists of moderators and facilitators, who can have either formal or informal role, and can be either paid professionals or recruited from within forum participants on a voluntary basis. In their more recent work, Graham and Wright (2014) state that, given the visibility and impact superposters could have in forum communities, as a subpopulation they are largely under-investigated. This is on the one hand related to 
the fact they are hard to get to, and on the other to the negative impression they might make, being labelled as a negative forum phenomenon, or over-dominating individuals, who aggravate equal participation of others. Based on their analysis of 25 superposters, Graham and Wright (2014) point out that superposters can also contribute forum discussions positively, through three groups of behaviour: consultative and supportive (advise giving, offering help), pedagogical (informing, clarifying, interpreting) and social bonding-based communicative forms (as the most common ones, including banter, chatter and storytelling).

Albrecht (2006) also studied a small group of superposters. He states that in an online setting, there is a small core of very active users, which resembles traditional political communication (where a few selected individuals make their views heard by a broad audience of passive listeners). Among 256 studied participants in an online political debate, $20 \%$ were the most active and responsible for more than three-quarters of the contributions. A total of 70 users took part in the survey (27\% female, a majority of them between 27 and 40 years old). Among them, there were 10 individuals with extreme activation (34.9\%). Albrecht finds that their online behavior also matches the positive 'old hands' role, meaning that $85 \%$ of their posts were in a form of replies to others' posts (which is significantly more than an average participant), while at the same time they received fewer comments than others. In other words, superposters contributed to the interactivity of the debate without profiting from it, and (as the content analysis of the debate posts suggests), they were not able to dominate the political discussion.

As it can be seen through this detailed introduction, the majority of scientific research in this field investigate types of motives (or gratifications) people fulfil in their everyday computer-mediated communication in general. Smaller proportion of research is dedicated specifically to forum-users and among them rarely few to superposters. Although superposters represent a minority in forum settlements, their high involvement and intense activity makes them very visible and potentially influential in forming public opinion on various topics. As they are a small population which is hard to get to, it is often easier to infer on their impact and participation patterns by analysing their posts. Even so, a clear scientific consensus on superposters' role does not exist. Moreover, by concentrating on content, rather than on the author, participation motives remain hidden and unclear. The fact alone, that someone spends several hours per day anonymously and actively contributing to forum discussions makes this subpopulation interesting for investigation. As with every other human behaviour that is practised in an extremely high frequency or duration, it is assumed that superposters' forum usage entails some other patterns and motives that surpass the average use. Although some of them probably use forums superficially, often changing topics and interlocutors (just posting more often than the average user), for others, forum participation could be an important part of identity, as they gradually become members of virtual communities. Virtual communities are defined as virtual settlements where members have developed 
mutual affective bonds (Jones, 1997). Blanchard and Markus (2004) found that virtual communities are characterised by the membership, belonging, group symbols, mutual influence, exchange of support and emotional connections among members. Moreover, they found that the behavioural processes that contribute to the sense of virtual community are similar to those found in non-virtual communities, such as exchanging support, creating identities and making identifications, and the production of trust.

Therefore, in this, basically explorative research, the focus was specifically on superposters in order to determine who they typically are and why they choose to spend so much time in anonymous online communication (what are the patterns and motives of their forum participation).

\section{Research Goal and Hypothesis}

The main aim of this study was to identify factors which motivate extremely active forum members (superposters) to contribute to forum activity.

Three research questions were set:

1. Who are typical superposters (in terms of gender, age, education, employment and marital status)?

2. What are their most dominant motives for extreme forum participation?

3. Are there any significant differences between superposters of different socio-demographic characteristics in prevailing motives for using forums?

According to the previously mentioned research, the basic assumption is that in a subpopulation of superposters the motives which typically occur with average users will also be present (e.g. information exchange, venting negative feelings, entertainment). However, as they spend several hours per day on forum communication, and are probably members of virtual communities, additional assumption is that some "higher-order" motives might be present as well, such as gaining recognition or boosting self-esteem through the process of social support exchange. Moreover, previous research suggests that more altruistic motives are of higher importance to female than male participants, while entertainment is more important to males.

\section{Methodology}

\section{Participants}

Participant group consisted of 112 highly engaged members of Croatia's portal Forum.hr (superposters). Highly engaged forum activity is operationalized as having a minimum of 8,000 posts in total. Out of 112 participants, $55 \%$ were male, 35 years old on average ( $M=35, S D=10.55$, age ranging from 15 to 65 years), mostly holding 
a master's degree $(33.9 \%)$, high school degree $(28.6 \%)$ or university baccalaureate degree $(25 \%)$. Most of them are employed $(60 \%)$ or are studying $(19.6 \%)$, and additional $11 \%$ are unemployed or retired $(6 \%)$. Also, most of them are married (41\%) or in a relationship (23\%), and approximately one-third of them are single. On average, participants have been active forum members for 7 years $(S D=3.2)$.

\section{Instrument}

A combined closed-ended and open-ended type of survey questionnaire was constructed for the purpose of this research. Besides general demographic data (gender, age, education, employment status and marital status), additional information were collected: the length of participation in forum discussions, the intensity of forum activity, the first topic that participants left their comments on, and initial motivation for joining the forum.

The main part of the questionnaire was the list of 58 potential motives for active forum discussion. This list was generated based on the content analysis of forum discussion topics, semi-structured interviews with a long-term forum superposter and moderator, and the items used in previously cited research (Korgaonkar \& Wolin, 1999; Leung, 2013; Papacharissi \& Rubin, 2000; Price, Leong, \& Ryan, 2005). Since categories and items were overlapping in these research, a new rough categorization of items was made, with the majority of items covering the first two categories. Categories were: information benefit (e.g. To get information related to my health or the health of a member of my family/friends; To get information before buying something; To learn something new; Because I get information quickly and in large quantities); emotional and self-concept benefit (e.g. So I do not feel lonely; To share my frustrations; To get emotional support for some decision I have to make; Because forum members respect my opinions more than people in my environment; Because I am anonymous and I can be the person I want to be; Because in my life I do not have much opportunity to show my strengths); socializing benefit (e.g. To meet new people virtually; For potential face to face encounters; To find and to chat with similar-minded; Simply because I like to communicate about certain topics; To have fun); altruism (e.g. To help others with my knowledge or experience; Because I see someone in trouble; Because the issue is important to the community and to other people) and financial benefit (e.g. To sell something; To advertise myself or my company; To gain some material rewards or conveniences as a result of my participation).

Participants had to assess to what extent a particular motive is present in their everyday forum participation (5-point scale ranging from 1 - not at all to 5 - very highly present). 


\section{Procedure}

An electronic version of the questionnaire and an invitation letter were sent to registered Forum.hr superposters. Forum.hr is the leading Croatian forum portal with over 430,000 listed members (www.forum.hr; March 2016), out of which approximately 600 members left more than 10,000 posts, while the most active of them wrote over 64,000 . The initial sampling strategy was to choose the most extreme of all the registered members, the ones that have been spending several hours a day communicating on forums, posting around 10 messages per day, in a period of several years. This rough calculation yielded the result of 10,000 posts, and initially only those forum members were contacted through private messaging system available on their personal profiles. Due to the low response rate, this criterion was lowered to 8,000 posts. Although the accompanying invitation letter called for anonymous participation in scientific research, the majority of 400 personally invited superposters were not motivated to respond. Finally, a personal contact with one of Forum.hr moderators was used, and he posted the link himself under several highly visited topics. Combination of these approaches yielded the final sample of 112 respondents.

\section{Results}

The majority of participants (42\%) spend between 1 and 3 hours a day on forums (reading and writing), and additional $24 \%$ less than one hour per day (variable - the intensity of forum activity; Figure 1). There are also $8 \%$ of currently inactive participants that spend several hours per month on forums.

Figure 1. The Intensity of Forum Activity among Superposters

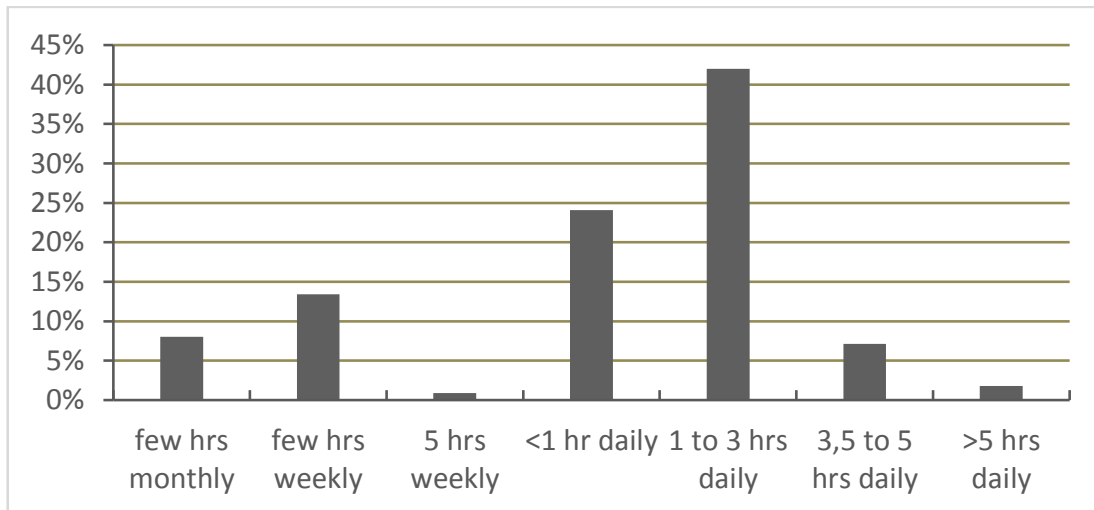


The first open-ended type of question asked the participants what was the first topic which motivated them to leave a post (Figure 2). Majority of them replied that they do not remember $(n=45)$. Other answers were grouped, and the topic with the highest frequency was politics and religion $(n=16)$. The other topics mentioned, with fewer than five answers, were grouped into the category "other".

Figure 2. The First Forum Topic that Superposters Got Involved in

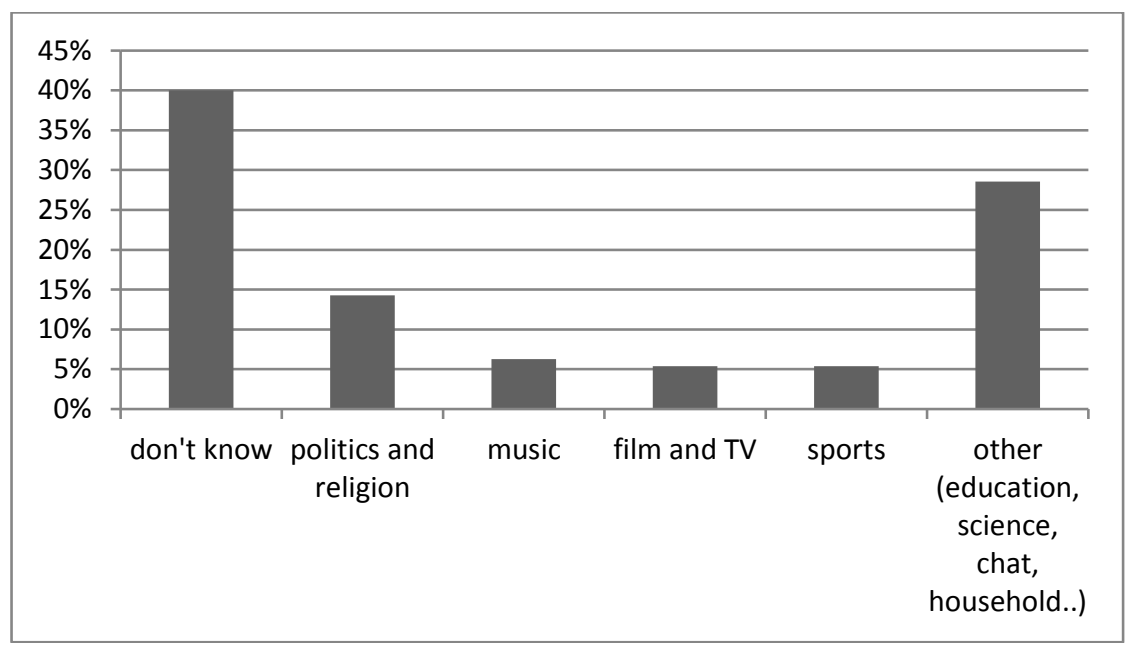

The second open-ended type of question, concerning motives for the first participation in forum discussions, was replied to with I do not remember by the majority of participants $(n=45)$. The rest of the answers were grouped and the highest frequency answers was reaction to someone else's post (to react to someone's incorrect information, to react to someone's different or stupid attitudes; $n=13)$, then to share one's own experience ( $n=10)$, to ask for concrete information $(n=4)$, to give the information needed $(n=3)$. The rest of the answers with lower frequencies were labelled as to socialize; out of boredom; because of a certain disappointment; because it was fun, etc.

The most important part of the questionnaire was the list of potential motives for active forum discussion. A principal component analysis (PCA) was conducted on the whole list of 58 items with direct oblimin rotation. The Kaiser - Meyer - Olkin measure verified the sampling adequacy for the analysis $(\mathrm{KMO}=0.741)$, and Bartlett's test of sphericity $\left(\lambda^{2}=444.155, d f=1653, p<.001\right)$ indicated that correlations between items were sufficiently large for PCA. After initial PCA, the items with small factor loading, or factor loadings on two or more factors were excluded. In other words, following Matsunaga's (2010) suggestions, in further analysis items with a factor loading higher of .40 were retained and rule $.60 / .40, .50 / .30$ was applied. 
For example, the excluded items with small factor loading (<.40) were: To sell something; To advertise myself or my company; To gain some material rewards or conveniences as a result of my participation; To achieve an intimate relationship with forum members etc. These items also have the lowest average grades (between 1 and 2) and low variability. It could be assumed that these motives are not relevant for superposters' forum activity. The examples of excluded items with factor loadings on two factors were: To express my dissatisfaction; To get emotional support for some decision; To show my real value etc. Some of these items are similar in content with some retained items (see Table 2).

Another principal component analysis was conducted on the remaining 28 items. The Kaiser - Meyer - Olkin measure $(\mathrm{KMO}=0.821)$ and Bartlett's test of

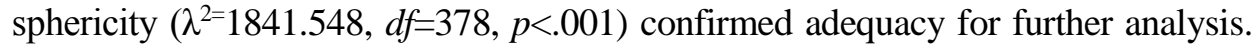
An initial analysis was run to obtain eigenvalues for each component in the data. Six components had eigenvalues over Kaiser's criterion of 1 and altogether explained $68.05 \%$ of the analysed item variance. The Scree plot showed inflexion that indicated retaining three components, which was also confirmed with results of a parallel analysis (28 variables x 112 participants, Table 1).

Table 1. Monte Carlo PCA for Parallel Analysis

\begin{tabular}{cccc}
\hline & Random Eigenvalue & Standard Deviation & Eigenvalue \\
\hline 1 & 2.07 & 0.10 & $\mathbf{8 . 7 3}$ \\
2 & 1.91 & 0.08 & $\mathbf{4 . 0 0}$ \\
3 & 1.78 & 0.06 & $\mathbf{2 . 5 7}$ \\
4 & 1.66 & 0.05 & 1.39 \\
5 & 1.57 & 0.04 & 1.30 \\
6 & 1.48 & 0.05 & 1.07 \\
$\ldots$ & & & \\
\hline
\end{tabular}

Number of variables: $\quad 28$

Number of subjects: 112

Number of replications: 100

This solution proved to be psychologically the most interpretable one, so three components were retained in the final analysis which explained $54.6 \%$ of the item variance. Table 2 shows the factor loadings after direct oblimin rotation. The items that cluster on the same components suggest that component 1 represents self-esteem, component 2 information exchange, and component 3 confrontation. 
Table 2. PCA Results for the Superposter's Motives Questionnaire

\begin{tabular}{|c|c|c|c|c|c|c|}
\hline & \multicolumn{3}{|c|}{$\begin{array}{c}\text { Pattern Matrix } \\
\text { Component }\end{array}$} & \multicolumn{3}{|c|}{$\begin{array}{c}\text { Structure Matrix } \\
\text { Component }\end{array}$} \\
\hline & 1 & 2 & 3 & 1 & 2 & 3 \\
\hline $\begin{array}{l}\text { Because forum members show more gratitude } \\
\text { than the people from my environment }\end{array}$ & .91 & .05 & -.08 & .87 & -.23 & .21 \\
\hline $\begin{array}{l}\text { Because I think my true value is not } \\
\text { recognized in my environment }\end{array}$ & .91 & .02 & -.01 & .90 & -.28 & .28 \\
\hline $\begin{array}{l}\text { Because in my life I do not have much } \\
\text { opportunity to show my strengths }\end{array}$ & .86 & .01 & -.05 & .84 & -.26 & .23 \\
\hline $\begin{array}{l}\text { Because forum members give me more } \\
\text { support than the people from my environment }\end{array}$ & .86 & .01 & .06 & .87 & -.28 & .34 \\
\hline $\begin{array}{l}\text { Because forum members respect my opinions } \\
\text { more than people in my environment }\end{array}$ & .83 & .16 & .04 & .79 & -.12 & .28 \\
\hline $\begin{array}{l}\text { Because at some level I feel like an outsider } \\
\text { (different from the others) and here I found } \\
\text { similar others }\end{array}$ & .76 & -.09 & -.03 & .78 & -.33 & .23 \\
\hline To share my concerns & .55 & -.24 & .10 & .66 & -.44 & .32 \\
\hline To share my frustrations & .53 & -.18 & .24 & .66 & -.39 & .44 \\
\hline $\begin{array}{l}\text { So that some expert in the area can give me } \\
\text { advice }\end{array}$ & -.06 & -.83 & -.07 & .19 & -.80 & .05 \\
\hline $\begin{array}{l}\text { Because I repeatedly find useful information } \\
\text { on the forum }\end{array}$ & -.06 & -.77 & .01 & .19 & -.75 & .12 \\
\hline $\begin{array}{l}\text { To get information before buying some } \\
\text { product (e.g. tourist arrangements, universities, } \\
\text { car purchase), i.e. some greater financial } \\
\text { investment }\end{array}$ & -.08 & -.76 & -.13 & .13 & -.71 & -.02 \\
\hline To learn something new & -.03 & -.74 & -.02 & .20 & -.72 & .09 \\
\hline $\begin{array}{l}\text { Because I can quickly get a lot of advice/ } \\
\text { information from unbiased people }\end{array}$ & -.13 & -.73 & .08 & .14 & -.70 & .17 \\
\hline $\begin{array}{l}\text { To get information related to my health or the } \\
\text { health of a member of my family/friends }\end{array}$ & .05 & -.72 & -.13 & .24 & -.72 & .01 \\
\hline
\end{tabular}


Table 2. - Continued.

\begin{tabular}{|c|c|c|c|c|c|c|}
\hline & \multirow{2}{*}{\multicolumn{3}{|c|}{$\begin{array}{c}\text { Pattern Matrix } \\
\text { Component }\end{array}$}} & \multirow{2}{*}{\multicolumn{3}{|c|}{$\frac{\text { Structure Matrix }}{\text { Component }}$}} \\
\hline & & & & & & \\
\hline & 1 & 2 & 3 & 1 & 2 & 3 \\
\hline $\begin{array}{l}\text { To help others with my knowledge or } \\
\text { experience }\end{array}$ & -.01 & -.69 & .03 & .23 & -.69 & .14 \\
\hline $\begin{array}{l}\text { Because I get information quickly and in large } \\
\text { quantities }\end{array}$ & .09 & -.68 & -.02 & .30 & -.71 & .12 \\
\hline $\begin{array}{l}\text { I will eventually need some information, so to } \\
\text { repay upfront }\end{array}$ & .12 & -.64 & -.07 & .30 & -.67 & .07 \\
\hline To share experience & .27 & -.54 & .09 & .48 & -.65 & .27 \\
\hline To pay tribute to someone & -.02 & -.54 & .23 & .23 & -.57 & .32 \\
\hline To support another person & .20 & -.44 & .03 & .36 & -.52 & .17 \\
\hline To share my failures & .22 & -.44 & .16 & .42 & -.54 & .30 \\
\hline To provoke people a little & -.11 & .17 & .83 & .10 & .07 & .76 \\
\hline To deal with forum member who annoys me & .05 & .15 & .76 & .24 & .01 & .75 \\
\hline To make jokes about someone & -.02 & .08 & .74 & .19 & -.04 & .72 \\
\hline $\begin{array}{l}\text { To deal with someone or something } \\
\text { concretely }\end{array}$ & .14 & .09 & .72 & .34 & -.07 & .75 \\
\hline To vent myself & .07 & -.24 & .62 & .34 & -.36 & .68 \\
\hline To have fun & -.05 & -.26 & .59 & .23 & -.34 & .62 \\
\hline $\begin{array}{l}\text { To stand up for my values and defend them } \\
\text { from others }\end{array}$ & .11 & -.16 & .51 & .33 & -.28 & .57 \\
\hline Eigenvalues & 8.73 & 4.00 & 2.57 & & & \\
\hline$\%$ of item variance & 31.17 & 14.28 & 9.17 & & & \\
\hline Cronbach's alpha & .91 & .89 & .91 & & & \\
\hline
\end{tabular}

Note. Factor loadings $>.40$ are in boldface

The first component labelled as self-esteem contains items related to receiving social support from other members, sharing concerns and having the opportunity to show one's own true values, not recognized in non-virtual world. The second component labelled as information exchange has high factor loadings mostly on the items concerning exchange of useful information, i.e. giving and asking for advice, including professional advice, medical advice, advice related to some purchase, as well as some private decisions advice. The third component labelled as confrontation contains items describing possibilities of provoking, dealing with annoying individuals, venting and having fun. Average results were also calculated for each component. Information exchange has the highest results $(M=2.99, S D=0.84)$, followed by confrontation $(M=2.39, S D=0.81)$ and self-esteem $(M=1.76, S D=0.84)$. 
All three components have high reliabilities (self-esteem Cronbach's $\alpha=.91$; information exchange Cronbach's $\alpha=.89$; confrontation Cronbach's $\alpha=.91$ ).

The correlation matrix between the components shows that all three components are significantly interrelated. Correlation coefficient between selfesteem and confrontation is the highest $(r=.43, p<.01)$, followed by correlation between self-esteem and information exchange $(r=.39, p<.01)$, and information exchange and confrontation $(r=21, p<.05)$. Table 3 shows significant correlations between all three components, with age and intensity of forum activity. The significant correlation was found between age and component 1 , demonstrating that the younger participants use forums more for boosting self-esteem. In addition, a significant correlation was found between the intensity of forum activity and components 1 and 3, suggesting that the more time someone spends on forums the more he or she tends to boost their self-esteem through it, and confront with differentminded.

Table 3. Correlation Matrix for Three Components, Age and Intensity of Forum Activity

\begin{tabular}{lcc}
\hline Components & Age & $\begin{array}{c}\text { Intensity of forum } \\
\text { activity }\end{array}$ \\
\hline 1. Self-esteem & $-.28^{* *}$ & $\mathbf{. 4}^{* *}$ \\
2. Information exchange & -.16 & .13 \\
3. Confrontation & -.04 &. $\mathbf{2 4}^{* *}$ \\
\hline
\end{tabular}

${ }^{*} p<.05 ;{ }^{* *} p<.01$.

However, according to Cohen (1988, as cited in Pallant, 2011), those correlations are weak. Age explains only $8 \%$ of the variance, and time spent on forums explains only $6 \%$ of the variance.

An independent-samples $t$-test was conducted in order to compare results between male and female participants on all three components. Female participants show higher results on subscales self-esteem $(M=2.10, S D=0.90)$ and information exchange $(M=3.25, S D=0.71)$ than male participant $(M=1.51, S D=0.70$ for selfesteem; $M=2.80, S D=0.88$ for information exchange), and these differences are statistically significant [self-esteem $t(102)=3.61, p=.001$; information exchange $t(102)=2.85, p=.005]$. This represents a medium-sized effect (eta squared for selfesteem is $\eta^{2}=.113$, and for information exchange $\eta^{2}=.074$ ). The gender difference for subscale confrontation was not significant [female $M=2.41, S D=0.71$; male $M=2.40$, $S D=0.88 ; t(102)=0.02, p=.983]$.

Furthermore, an independent-samples $t$-test was conducted in order to compare results between participants with middle $(n=33)$ and higher education $(n=75)$, and the differences were not significant on any of three components [self-esteem 
$t(101)=1.78, p=.078$; information exchange $t(101)=1.94, p=.055$; confrontation $t(101)=1.47, p=.145]$.

A one-way between-subjects ANOVA was conducted in order to explore the differences in all three components between participants of different relationship/ marital status. The participants were divided into three groups (single, in a relationship, married). The difference between groups were not significant for selfesteem $[F(2,99)=0.22 ; p=.805]$ and information exchange $[F(2,99)=0.07, p=.903]$. On the other hand, there was a significant difference between groups on a component confrontation $\left[F(2,99)=4.04, p=.021, \eta^{2}=.075\right]$. Post hoc analysis (Tukey's HSD test) showed significant difference ( $p=.016)$ between single $(n=34, M=2.11, S D=0.63)$ and married $(n=44, M=2.61, S D=0.80)$ participants, whereas differences between participants who are in a relationship $(n=24, M=2.45, S D=0.94)$ and other two groups were not significant.

\section{Discussion}

The first research question was Who are the people who spend such a large amount of time communicating online with strangers, hidden behind pseudonyms? In this research, the superposter was defined as someone who posted a minimum of 8,000 comments. The average superposter is 35 years old, holds a university degree, is employed and emotionally engaged, and has been posting actively since he or she was 28 years old. Although some older articles marked heavy internet users as socially isolated (Kraut et al., 1998), some other research showed that to be a kind of prejudice. Analysing many studies conducted on internet usage that published between 1995 and 2001, Katz and Rice (2002) demonstrated that not only the internet users not isolated, but also that they are more active in political and civil life, and have more social interaction both in the virtual and the real world. Bubaš (2000) emphasizes this paradox of the internet, which is reflected in the fact that individuals with deficient social skills would compensate communication in virtual world and reduce contacts with others, while people who tend to socialize in real life will probably take advantage of this medium for more frequent socializing.

This brings us to the next research question why, i.e. what motivated and is still motivating superposters for such an engagement. The majority of participants do not remember what the first topic they posted on was or what made them do so. It may be that active forum participants change their habits in using forum over time. As superposter interviewee said - First you chat casually, you want to have fun, to find some friends and partners. Then, after you find a partner, you chat about weddings, then about apartments and house construction topics, then about pregnancies and kids, etc.

The answer with the second highest frequency (14\%) was politics and religion. Among many listed topics on Forum.hr, politics is the one with the highest number 
of posts (more than 3,500 000) and with more than 19,000 subtopics (www.forum.hr; March 2016). Many findings in this field have shown that social media is an arena for venting negative emotions (Chmiel et al., 2011a, 2011b; Hennig-Thurau, Gwinner, Walsh, \& Gremler, 2004; Lapidot-Lefler \& Barak, 2012; Lee \& Hu, 2004; Wang \& Shih, 2014). Chmiel et al. (2011a) suggest that emotional expressiveness "is the fuel that sustains some e-communities". People could feel calm or relaxed after venting and it could help them deal with their negative emotions. There are entire web sites, so-called rant-sites, where people can vent about whatever they like. To many active forum members the ability to discuss some topic, provoke others or get provoked is an idea of entertainment. In this research a similar motive for extreme forum participation (named confrontation) was determined.

This research also demonstrates that among the three determined superposters' motives, information exchange had the highest average grade, followed by confrontation, and at last self-esteem. In the content analysis of online forum posts made by 25 superposters with more than 2,000 posts (Graham \& Wright, 2014), four clusters of forum participation pattern were identified. These were: 1) storytelling/ providing personal information, banter/humour; 2) advice giving/helping, requesting advice/help, acknowledgements; 3) arguing/debating, interpreting/clarifying, providing factual information; 4) degrading and curbing. Although that was content analysis, a parallel can be made with three motives determined in this research.

In other previous research on the internet usage motives in general, information exchange motive appeared to be among the most salient ones (e.g. Korgaonkar \& Wolin, 1999; Pappacharissi \& Rubin, 2000; Price et al., 2005). Also, some research mention venting negative emotions (e.g. Leung, 2013) and enjoying debate motives (Rojo \& Ragsdale, 1997) which can be related to confrontation motive found in this research. However, there is little mention on self-esteem motive, although Leung (2013) speaks of similar recognition needs (needs to promote or publicise expertise, establish personal identity, and gain respect and support). An assumption can be made, that these kinds of motives are not among the salient ones, because it takes time and commitment to become a member of a real virtual community, and with time members form mutual social ties, exchange social support, and become mutual sources of self-esteem boosting (in a similar manner as in non-virtual communities). As their roles evolve, they gain more experience, develop wider and deeper network and gain more credit or higher status in other members' eyes. Once in a role of a novice with fewer posts, active members evolve to moderators, have their followers, and their word counts for more, which gives them the opportunity to satisfy other, higher-order motives. This is probably even more present in forum communities gathered around some personal topics (such as illness, raising children, pregnancy etc.), rather than in topics that serve as an arena for emotional venting and confrontation (such as politics and religion). In this research, the main topic that a participant is involved in was not controlled, so this assumption should be further 
tested. In other words, using forums for boosting self-esteem could be a specificity of superposters.

Furthermore, in this research, all three motives are positively inter-correlated. Papacharissi and Rubin (2000) found a negative correlation between using the internet for interpersonal utility and for information seeking. However, their research was conducted on a population that uses internet less than an hour per day, so results of this research might be another specificity of an extreme internet (i.e. forum) usage.

In the context of the third research question, analysis of the differences in forum participation patterns within superposters' group was also conducted. Even though all participants are labelled as superposters (with a minimum of 8,000 posts), there was a small but significant correlation between the intensity of forum activity and components 1 and 3 . This could imply that even in a group of generally highly active forum participants there is a distinction between those who are extremely active (practising forum discussions for more than several hours per day), and the ones with lower levels of engagement. The latter (although still considered highly active compared to the general population) use forums more for practical purposes - sharing their experiences and seeking advice. The ones with extreme levels of participation do that too, but they confront others and boost their self-esteem through forums more. However, in the entire sample, all three motives are significantly and positively intercorrelated, suggesting that all of them are present in intensive forum activity.

Gender also plays an important role in describing forum behaviour. Women use forums more for self-esteem boosting as well as for sharing and seeking information in different areas. This is in line with previous research. Herring $(1994,1996)$ found gender differences in online communication motives and styles. Requesting and providing information is more common in female than in male discussions. The male style in posting is more often characterized by antagonism, such as put-downs, selfpromotion, sarcasm, strong confrontation, etc. In addition, previous research has demonstrated that men are more likely to post longer messages, which are more often critical and insulting; they more often begin and close discussions, and bring up their opinions as "facts". Women tend to post relatively short messages, their arguments are more often based on intuition and experience, and they express more doubts, apologies and suggestions as well as support (Herring, 1994, 1996, 2003; Herring, Johnson, \& DiBenedetto, 1995; Sutton, 2012). Herring (1994) explains this through different communication ethics in men and women. Women place a higher value on consideration for the needs of others, whereas men assign a greater value to freedom from censorship, open expression, and agonistic debate.

Additionally, age is an important factor in describing active forum behaviour, as it has been shown that the younger participants more often use forums for selfesteem. As a young superposter interviewee in this research said - On forum you can be anyone you like - smarter, prettier, and younger. You could be a total failure in your real life, and still be a person that the others will follow, support and seek advice from on forums. Besides the evident explanation that younger participants are less 
educated, less often employed and less often married (which all can be the sources of self-esteem), younger generations generally use internet more, and are probably more aware of its various opportunities.

Finally, this research has several limitations that should be properly addressed. Firstly, although the proportion of highly active forum members is small (at this point approx. $0.2 \%$ out of all the registered Forum.hr members), this sample got even smaller due to the unwillingness of forum members to participate in the research. As response rate was around 32\%, it remains unclear whether those who replied were representative of the target population. It is possible that those who are more inclined to sharing information in virtual settlements are more inclined to helping scientific purposed as well.

Secondly, although all participants posted at least 8,000 posts in total, some of them claim to be rather inactive currently, so their recollection on participation motives could be questionable. In other words, it remains unknown whether these posts were actively written a month ago or a year ago, so it would have been better to have several measures on forum activity in order to better understand the nature of its usage. One of them could also be the number of written posts, as it ranges from 8,000 to more than 64,000 . Furthermore, it would be useful to measure what (besides the given advantages) the main disadvantages of forum activity are, i.e. what are its consequences on daily functioning. For the most extreme among the extreme posters, the amount of time and energy spent on forums could be considered even as a form of addiction, although it is still not clear where the line between heavy internet usage and internet addiction is. Two different directions are evident in the literature: compulsive internet use (addiction) and negative effect related to time spent on internet (such as depression, loneliness, etc.). Online community activities were much more intense in internet addict groups, whereas email and information searching were more often found in non-addict group (Byun at al., 2009; Chou, Chou, \& Tyan, 1998; Chou \& Hsiao, 2000; Simkova \& Cincera, 2004; Whang, Lee, \& Chang, 2003).

Due to the fact that a new questionnaire was constructed and used, another limitation of this research lies in the absence of control group consisted of average forum users. Having a control group would enable a deeper understanding of the specifics regarding motives and other habits of superposters in the virtual environment. The final recommendation for future research is to focus on qualitative, more in-depth investigation of highly active forum members.

The main contribution of this research lies in the fact that its thesis were tested on a minority of forum members' population which is difficult to reach and is generally under-investigated. To an average forum lurker, the fact that some information or attitudes are written several times in different places could be proof of its credibility. At the same time, they could overlook that it has been written by the same, extremely active forum member. Their extreme activity makes them 
influential, and at the same time, their activity under specific topic does not reflect the level of their expertise.

\section{Conclusion}

The infinite variety of open forum topics leads to the conclusion that forums have outgrown their once instrumental value (exchange of specific information), or value as a platform for fun and chat, and have also become media for satisfying "higher-order" psychological needs. For a minority of extremely active forum participants, the latter is particularly true.

In this research three basic motivation factors of active forum participation were empirically identified. These were information exchange, self-esteem, and confrontation. Even within the group of extremely active forum participants (with more than 8,000 posts), a small but significant differentiations in patterns of activity were found. The most active of them use forums more for self-esteem and for confrontation. Female and younger participants were also found to be more active for the purpose of boosting self-esteem. Women are also more active in information sharing, which is all in line with previous research.

The main value of this research is in its scope, as the studies of motives of extremely active forum members are limited. However, this study should be approached with caution because of the limited response rate among the active forum members. Consequently, the findings of this study should be further tested on a larger sample from a wide variety of virtual communities.

\section{References}

Albrecht, S. (2006). Whose voice is heard in online deliberation?: A study of participation and representation in political debates on the internet. Information, Communication, \& Society, 9(1), 62-82. doi:10.1080/13691180500519548

Barack, A. (2007). Emotional support and suicide prevention through the Internet: A field project report. Computers in Human Behavior, 23, 971-984. doi:10.1016/j.chb.2005. 08.001

Berger, M., Wagner, T.H., \& Baker, L.C. (2005). Internet use and stigmatized illness. Social Science \& Medicine, 61(8), 1821-1827. doi:10.1016/j.socscimed.2005.03.025

Blanchard, A.L., \& Markus, M.L. (2004). The experienced sense of a virtual community: Characteristics and processes. ACM Sigmis Database, 35(1), 64-79. doi:10.1145/ 968464.968470

Brownlow C.L. (2007). The construction of the autistic individual: Investigations in online discussion groups. (Doctoral dissertation), University of Brighton, Brighton. 
Bubaš, G. (2000). Paradoksi Interneta kao komunikacijskog medija. Medijska istraživanja, $6(2), 5-23$.

Byun, S., Ruffini, C., Mills, J.E., Douglas, A.C., Niang, M., Stepchenkova, S., ... Blanton, M. (2009). Internet addiction: Metasynthesis of 1996-2006 quantitative research. CyberPsychology \& Behavior, 12(2), 203-207. doi:10.1089/cpb.2008.0102

Cheung, C.M., Lee, M.K., \& Rabjohn, N. (2008). The impact of electronic word-of-mouth: The adoption of online opinions in online customer communities. Internet Research, 18(3), 229-247. doi:10.1108/10662240810883290

Chmiel, A., Sienkiewicz, J., Thelwall, M., Paltoglou, G., Buckley, K., Kappas, A., \& Hołyst, J.A. (2011a) Collective emotions online and their influence on community life. PLoS ONE, 6(7), 1-8. doi:10.1371/journal.pone.0022207

Chmiel, A., Sobkowicz, P., Sienkiewicz, J., Paltoglou, G., Buckley, K., Thelwall, M., \& Hołyst, J.A. (2011b). Negative emotions boost user activity at BBC forum. Physica A: Statistical Mechanics and its Applications, 390(16), 2936-2944.

Chou, C., Chou, J., \& Tyan, N.C.N. (1998). An exploratory study of internet addiction, usage and communication pleasure. Paper presented at the Association for Educational Communications and Technology Annual Meeting.

Chou, C., \& Hsiao, M.C. (2000). Internet addiction, usage, gratification, and pleasure experience: The Taiwan college students' case. Computers \& Education, 35(1), 65-80. doi:10.1016/S0360-1315(00)00019-1

Finfgeld, D.L. (2000). Therapeutic groups online: The good, the bad, and the unknown. Issues in Mental Health Nursing, 21, 241- 255. doi:10.1080/016128400248068

Forum (March 2016). Retrieved from www.forum.hr

Graffigna, G., \& Bosio, A.C. (2008). The influence of setting on findings produced in qualitative health research: A comparison between face-to-face and online discussion groups about HIV/AIDS. International Journal of Qualitative Methods, 5(3), 55-76.

Graham, T., \& Wright, S. (2013). Discursive equality and everyday talk online: The impact of "superparticipants". Journal of Computer-Mediated Communication, 19(3), 625-642. doi:10.1111/jcc4.12016

Graham, T., \& Wright, S. (2014). Analysing 'super-participation' in online third spaces. In M. Cantijoch, R. Gibson, \& S. Ward (Eds.), Analyzing social media data and web networks (pp. 197-215). Basingstoke, UK: Palgrave, Macmillan.

Hennig-Thurau, T., Gwinner, K.P., Walsh, G., \& Gremler, D.D. (2004). Electronic word of mouth via consumer-opinion platforms: What motivates consumers to articulate themselves on the Internet? Journal of Interactive Marketing, 18, 38-52. doi:10.1002/ dir. 10073

Hernández-Ramos, P. (2004). Web logs and online discussions as tools to promote reflective practice. The Journal of Interactive Online Learning, 3(1), 1-16.

Herring, S.C. (1994). Politeness in computer culture: Why women thank and men flame. In M. Bucholtz, A. Liang, \& L. Sutton (Eds.), Cultural performances: Proceedings of the 
Third Berkeley Women and Language Conference (pp. 278-94). Berkeley: Berkeley Women and Language Group.

Herring, S.C. (1996). Gender and democracy in computer-mediated communication. In R. Kling (Ed.), Computerization and controversy (2nd edition, pp. 476-489), New York: Academic Press.

Herring, S.C. (2003). Gender and power in on-line communication. In J. Holmes \& M. Meyerhoff (Eds.), The handbook of language and gender (pp. 222-228). Oxford, UK: Blackwell Publishing Ltd. doi:10.1002/9780470756942.ch9

Herring, S.C., Johnson, D., \& DiBenedetto, T. (1995). 'This discussion is going too far!' Male resistance to female participation on the Internet. In M. Bucholtz \& K. Hall (Eds.), Gender articulated: Language and the socially constructed self (pp. 67-96). New York: Routledge.

Horgan, A., \& Sweeney, J. (2010). Young students' use of the Internet for mental health information and support. Journal of psychiatric and Mental Health Nursing, 17(2), 117 123. doi:10.1111/j.1365-2850.2009.01497.x

Jones, Q. (1997). Virtual-communities, virtual settlements \& cyber-archaeology: A theoretical outline. Journal of Computer-Mediated Communication, 3(3). doi:10.1111/j. 1083-6101.1997.tb00075.x

Katz, J.E., \& Rice, R.E. (2002). Social consequences of Internet use: Access, involvement, and interaction. IT \& Society, 1(1), 166-179.

Keeler, C.G., \& Horney, M. (2007). Online course designs: Are special needs being met? The American Journal of Distance Education, 21(2), 61-75. doi:10.1080/ 08923640701298985

Korganonkar, P.K., \& Wolin, L.D. (1999). A multivariate analysis of web usage. The Journal of Advertising Research, 39(2), 53-69.

Kraut, R., Patterson, M., Lundmark, V., Kiesler, S., Mukophadhyay, T., \& Scherlis, W. (1998). Internet paradox: A social technology that reduces social involvement and psychological well-being? American Psychologist, 53(9), 1017-1031. doi:10.1037// 0003-066X.53.9.1017

Kummervold, P.E., Gammon, D., Bergvik, S., Johnsen, J.A.K., Hasvold, T., \& Rosenvinge, J.H. (2002). Social support in a wired world: Use of online mental health forums in Norway. Nordic Journal of Psychiatry, 56(1), 59-65. doi:10.1080/ 08039480252803945

Lapidot-Lefler, N., \& Barak, A. (2012). Effects of anonymity, invisibility, and lack of eyecontact on toxic online disinhibition. Computers in Human Behavior, 28(2), 434-443. doi:10.1016/j.chb.2011.10.014

Lee, C.C., \& Hu, C. (2004). Analyzing hotel customers' e-Complaints from an Internet complaint forum. Journal of Travel \& Tourism Marketing, 17(2/3), 167-181. doi:10.1300/J073v17n02_13 
Lee, S., Kim, J.H., \& Rosen, D. (2009). A semantic network and categorical content analysis of Internet and online media research. The Open Communication Journal, 3, 15-28. doi:10.2174/1874916X00903010015

Leung, L. (2013). Generational differences in content generation in social media: The roles of the gratifications sought and of narcissism. Computers in Human Behavior, 29(3), 997-1006. doi:10.1016/j.chb.2012.12.028

Malaspina, C. (2013). The spiral of silence and social media: Analysing Noelle-Neumann's phenomenon application on the Web during the Italian Political Elections of 2013, (Doctoral dissertation). London School of Economics and Political Science, London.

Matsunaga, M. (2010). How to factor-analyze your data right: Do's, dont's, and how-to's. International Journal of Psychological Research, 3(1), 97-110.

McCormack, A., \& Coulson, N. (2009). Individuals with eating disorders and the use of online support groups as a form of social support. Cyberpsychology: Journal of Psychosocial Research on Cyberspace, 3(2), 1-11. doi:10.1097/NCN. 0b013e3181c04b06

Pallant, J. (2011). SPSS priručnik za preživljavanje. Beograd: Mikro knjiga.

Palmer, S., Holt, D., \& Bray, S. (2008). Does the discussion help? The impact of a formally assessed online discussion on final student results. British Journal of Educational Technology, 39, 847-858. doi:10.1111/j.1467-8535.2007.00780.x

Papacharissi, Z., \& Rubin, A.M. (2000). Predictors of Internet use. Journal of Broadcasting and Electronic Media, 44(2), 175-196. doi:10.1207/s15506878jobem4402_2

Pitta, D.A., \& Fowler, D. (2005). Internet community forums: An untapped resource for consumer marketers. Journal of Consumer Marketing, 22(5), 265-274. doi:10.1108/ 07363760510611699

Price, L, Leong E., \& Ryan M. (2005). Motivations for social Internet use. ANZMAC Conference: Consumer Behaviour. Retrieved from http://www.anzmac.org/ conference_archive/2005/cd-site/pdfs/3-Consumer-Beh/3-Price.pdf

Rojo, A., \& Ragsdale, R.D. (1997). Participation in electronic forums: Implications for the design and Implementation of collaborative distributed multimedia. Telematics and Informatics, 14(1), 83-96.

Ruggiero, T.E. (2000). Uses and gratifications theory in the 21st century. Mass Communication \& Society, 3(1), 3-37. doi:10.1207/S15327825MCS0301_02

Seale, C., Ziebland, S., \& Charteris-Black, J. (2006). Gender, cancer experience and internet use: A comparative keyword analysis of interviews and online cancer support groups. Social Science \& Medicine, 62(10), 2577-2590. doi:10.1016/j.socscimed.2005.11.016

Seymour, W., \& Lupton, D. (2004). Holding the line online: Exploring wired relationships for people with disabilities. Disability and Society, 19(4), 291-305. doi:10.1080/ 09687590410001689421

Simkova, B., \& Cincera, J. (2004). Internet addiction disorder and chatting in the Czech Republic. CyberPsychology \& Behavior, 7(5), 536-539. doi:10.1089/cpb.2004.7.536 
Stafford, T.F., Stafford M.R., \& Schkade L.L. (2004). Determining uses and gratifications for the Internet. Decision Sciences, 35(2), 259-288. doi:10.1111/j.00117315.2004.02524.x

Sutton, L.A. (2012). Using usenet: Gender, power, and silence in electronic discourse. Annual Meeting of the Berkeley Linguistics Society, 20(1), 506-520. doi:10.3765/bls. v20i1.1480

Thomas, M.J. (2002). Learning within incoherent structures: The space of online discussion forums. Journal of Computer Assisted Learning, 18(3), 351-366. doi:10.1046/j.02664909.2002.03800.x

Thurlow, C., Lengel, L., \& Tomic, A. (2004). Computer mediated communication: Social interaction and the internet. Thousand Oaks, CA: Sage.

Wang, W., \& Shih, J. (2014). Factors influencing university students' online disinhibition behavior - The moderating effects of deterrence and social identity. International Journal of Social, Behavioral, Educational, Economic and Management Engineering, 8(5), 1477-1483.

Whang, L.S.M., Lee, S., \& Chang, G. (2003). Internet over-users' psychological profiles: A behavior sampling analysis on internet addiction. CyberPsychology \& Behavior, 6(2), 143-150. doi:10.1089/109493103321640338

Wojcieszak, M.E., \& Mutz, D.C. (2009). Online groups and political discourse: Do online discussion spaces facilitate exposure to political disagreement? Journal of Communication, 59, 40-56. doi:10.1111/j.1460-2466.2008.01403.x

Woong Yun, G., \& Park, S-Y. (2011). Selective posting: Willingness to post a message online. Journal of Computer-Mediated Communication, 16, 201-227. doi:10.1111/j.1083-6101.2010.01533.x 


\section{Analiza motiva sudjelovanja vrlo aktivnih sudionika u internetskim forumskim diskusijama}

\section{Sažetak}

Glavni je cilj ovoga istraživanja bio utvrditi motive sudjelovanja u internetskim (online) forumskim diskusijama iznimno aktivnih sudionika (tzv. superpostera). Za te je svrhe konstruiran opsežan internetski upitnik poslan članovima portala Forum.hr koji imaju više od 8000 objava. Konačan se uzorak sastoji od 112 sudionika. Analizom je glavnih komponenti dobiveno trokomponentno rješenje, koje objašnjava $54.6 \%$ varijance. Komponente su interpretirane kao samopoštovanje, razmjena informacija i konfrontacija. Nadalje, značajne su razlike u motivima sudjelovanja utvrđene između sudionika različitoga spola, dobi i stupnja forumske aktivnosti. Rezultati su interpretirani u svjetlu prijašnjih istraživanja.

Ključne riječi: društvena ponašanja na internetu, motivi komunikacije na forumima, superposteri, upitnik

\section{Análisis de los motivos de superposters para participar en las discusiones en los foros en línea}

\section{Resumen}

El objetivo principal de este trabajo fue identificar factores que motivan a los miembros extremadamente activos en los foros en línea para su participación diaria. Se construyó un cuestionario extensivo y éste fue enviado a los miembros de Forum.hr que tienen más de 8.000 posts. La muestra final consta de 112 miembros que respondieron. Análisis de componentes principales ha proporcionado una solución interpretable de tres componentes, explicando el $54.6 \%$ de la varianza. Las componentes eran autoestima, intercambio de informaciones y confrontación. Se encontraron algunas diferencias significativas también en las subescalas motivacionales y las variables de género, edad e intensidad de la actividad en el foro. Los resultados se discuten en relación con la investigación previa.

Palabras clave: conducta social en línea, motivos para la comunicación en el foro, superposters, cuestionario

Primljeno: 29.08.2016. 